\title{
Understanding the Interactions among the Barriers to Entrepreneurship Using Interpretive Structural Modeling
}

\author{
Ramin Raeesi ${ }^{1}$, Meisam Dastranj ${ }^{1}$, Sahar Mohammadi ${ }^{1} \&$ Ehsan Rasouli ${ }^{1}$ \\ ${ }^{1}$ Department of Industrial Management, Persian Gulf University, Bushehr, Iran \\ Correspondence: Ramin Raeesi, Department of Industrial Management, Persian Gulf University, Bushehr 75169, \\ Iran. Tel: 98-917-707-9307. E-mail: edu@pgu.ac.ir
}

Received: March 15, 2013

Accepted: April 25, 2013

Online Published: June 17, 2013

doi:10.5539/ijbm.v8n13p56

URL: http://dx.doi.org/10.5539/ijbm.v8n13p56

\begin{abstract}
Entrepreneurship brings about economic innovation and job formation, and its improvement can well account for the unemployment crisis. However, many barriers either stop entrepreneurs from entering the market, or lead their business to failure after entering. These barriers have been sparsely and case dependently reported in the literature, but, to the best of our knowledge, no studies have been yet designated to investigate the general barriers to entrepreneurship.

This paper tries to bridge this gap by reviewing the most relevant and available literature to elicit the major general barriers to entrepreneurship. Eleven general barriers to entrepreneurship are identified and supported by the related literature. Since these barriers are not independent and unconnected, but interrelated and interactive, understanding the interactions among them can help decision makers in determining appropriate overcoming measures. In order to model these interactions this paper utilizes interpretive structural modeling (ISM) which has shown to be an efficient approach for analyzing systematic interactions among barriers. We distinct barriers into two groups of inside and outside barriers and with the support of the ISM-based model, we show that inside barriers are dependent on outside barriers. Corrupted and unsupportive business environment then, shows to be the major driving barrier to entrepreneurship.
\end{abstract}

Keywords: entrepreneurship, barriers, Interpretive structural modeling (ISM)

\section{Introduction}

Reynolds et al. (1999) define entrepreneurship as any attempt at new business or new venture creation, such as self-employment, a new business organization, or the expansion of an existing business, by an individual, a team of individuals, or an established business. Entrepreneur, on the other hand, is the one who takes initiative, organizes some social-economic mechanisms, and accepts risk of failure (Shapero, 1975), and is distinguished by the qualities of commitment and determination, leadership, opportunity obsession, tolerance of risk and ambiguity, motivation to excel, creativity, self-reliance, and ability to adapt (Timmons, 1999).

Entrepreneurship contributes to innovation, development, job creation, and equitable income distribution (Hirschman, 1958; Baumol, 1990; Gorman et al., 1997). It has received much attention during the past decades, since new firm creation is a critical driving force of economic growth and leads to creation of hundreds of thousands of new jobs (Low \& MacMillan, 1988). University graduates, capital owners, innovators with novel business ideas, and motivated jobless individuals are all potential entrepreneurs, if only the suitable ground for their entry is provided.

Indeed, the idea of entrepreneurship has always been theoretically praised, but not practically paid to. There are numerous barriers that either impede entrepreneurs from entering the business market, or when they are finally entered, lead their business to failure. These barriers are frequently divided to barriers to entry and barriers to survival. Although the latter group is believed to be more severe (Audretsch, 1995), in case they are well identified and their interactions are recognized, suitable overcoming measures could be thought of. Many of these barriers have been reported in the literature, but rather sparsely or case dependently, and to the best of our knowledge no study has yet been devoted to investigate the general barriers to entrepreneurship. By general barriers we mean those barriers which seem to be all-inclusive and more or less true in the business context of most societies. 
This paper tries to bridge this gap by reviewing the most relevant and available literature to elicit the major barriers to entrepreneurship. We try to bring all the reported barriers of the same kind, with different terms and titles, under the same umbrella. Barriers in every system then, are often interrelated and one may alleviate, augment, reinforce, or cause the other and understanding these interactions is much substantial to arriving at reasonable overcoming measures. Moreover, it is not always possible or logical to overcome all the barriers in a system, due to resource, time, and capability constraints, and finding the main artery of the system is a real cost saving aid. Interpretive structural modeling (ISM) approach has been well adopted in the analysis of barriers interactions, and hence this paper too, makes use of ISM to understand the interactions among the barriers to entrepreneurship.

The rest of this paper is constructed as follows: section 2 of the paper reviews the related studies and tries to elicit the major barriers to entrepreneurship and present literature supports to these barriers in sub sections of the very section. Section 3 presents the principles of ISM and section 4 applies the steps of ISM approach on entrepreneurship barriers. Finally, section 5 is discussion and conclusion.

\section{The Related Literature: Barriers to Entrepreneurship}

In spite of the fact that entrepreneurship is an appealing field of study to academia, the number of specialized studies on barriers to entrepreneurship is limited and most of the related research have found these barriers in case dependent studies and to the best of our knowledge no particular study has been yet devoted to find general barriers to entrepreneurship.

Aidis and Adachi (2007) investigate the low level of new firm entry in Russia's business market and find some informal constraints which form barriers not only for new firm creation but also for firm survival and firm exit. Niu et al. (2011) focus on entry barriers in the business context of China. They survey one hundred and ninety three Chinese executives to ascertain the dimensions and order of importance of market entry barriers in China. Rajaei et al. (2011) try to identify factors affecting the development and strengthening of entrepreneurship in agricultural production cooperatives in Zanjan province in Iran. They use a descriptive-correlation survey approach and find that the most important factors in strengthening entrepreneurship in agricultural cooperatives are providing financial support and tax breaks, reforming the banking laws and making regulations to adjust with entrepreneurs conditions and preparing the document of national entrepreneurship development. Sandhu et al. (2011) collect data from a sample of 267 postgraduate students from various Malaysian universities to find their perception towards barriers to entrepreneurship. Their research suggests that the highest ranked barrier to entrepreneurship among Malaysian postgraduate students is lack of social networking followed by lack of resources and aversion to risk. Martins (2004) provides some information about barriers to create a business, among different groups in the societies of Portugal, France, Italy and the UK, and discuses success cases or practices of how to overcome the barriers. Yaghoubi (2010) investigates barriers to entrepreneurship promotion in agricultural higher education and finds that the most important barriers to entrepreneurship promotion in agricultural higher education are: Expansion of agricultural colleges, lack of fitness of educational content with the job market needs, traditional teaching methods that are incompatible with the interests of students, and insufficient attention to learning practical skills. Kanniainen and Poutvaara (2007) take a formal measure to identify several distortions which create barriers to entrepreneurship. They find entry costs caused by regulation, union wage policies, and inefficiencies in the transmission of tacit knowledge between generations of entrepreneurs, as main barriers. Khayri et al. (2011) investigate barriers to enhance entrepreneurship in the agricultural higher education and find that lack of adequate government support, limited financial ability, and lack of efficiency in universities to educate entrepreneur graduates, are the main barriers. Qunlian (2011) analyzes the main difficulties of university students' entrepreneurship in China and presents corresponding policy recommendations. Zhang et al. (2009) study the genetic basis of entrepreneurship and explore gender differences in the genetic influences on the tendency of people to become entrepreneurs. They find sharp difference in genetic influences on entrepreneurship across gender groups and highlight the different challenges that men and women face in their entrepreneurial endeavors. Barth et al. (2006) investigate diverse empirical literature on factors affecting entrepreneurship and patterns of small-business formation and growth in low- and moderate-income communities in the United States. Cupido (2002) researches for barriers to entrepreneurship in the Western Cape in his master thesis. His findings suggests that lack of management skills in small ventures is one of the key factors, as well as the difficulty the businessperson has to contend with when it comes to handling of red tape with the starting up of the venture.

After a rigorous review on the most available and relevant literature, this study identified 11 major barriers which generally impede the process of entrepreneurship. The rest of this section is allocated to the presentation of these barriers. Each subsection presents one of these barriers and provides supporting arguments from the 
literature.

\subsection{Market Entry Severe Regulations}

Governmental regulations in different economic contexts often frustrate entrepreneurs and obstruct their entry to business market. This is one of the most cited barriers to entrepreneurship in the related literature. Costly regulations impede the setting up of businesses and stand in the way of economic growth (De Soto, 1990). Different governmental rules including taxation laws, environmental regulations, lending, licensing, loan obtaining and others are all barriers to entrepreneurship (Lopez, 1999; Barth et al., 2006). Klapper et al. (2006) carry out of a comprehensive study of the effect of market entry regulations on the creation of new firms. They find that costly regulations hamper the creation of new firms, especially in industries that should naturally have high entry. This barrier is the same thing that Bemstein (2000) calls the "red tape". He argues that governmental bureaucratic process and complicated taxation are definite obstacles for the entrepreneur. Aidis and Adachi (2007) also maintain that predatory tax behavior of authorities may dissuade potential entrepreneurs from entering. Klapper et al. (2004) find entry procedures, property rights and tax disadvantages as some barriers to entrepreneurship. Martins (2004) argues that legal entry barriers should be avoided unless their benefits are very clear. She refers to the complexity of creating a company and states that in some countries, the entrepreneurs need one day to register an enterprise, in others, they need 20 weeks.

\subsection{Fear of Failure}

Some of the common barriers faced by entrepreneurs are psychological in nature (Sandhu et al., 2011). Entrepreneurs are always in dilemma of the tradeoff between "risk of missing the boat" versus the "risk of sinking the boat" (Dickson \& Giglierano, 1986), that is failure and entrepreneurship always go hand-in-hand (Sandhu, Sidique, \& Riaz, 2011). Indeed entrepreneurship is a high-risk activity (Qunlian, 2011), because the market for entrepreneurs is always in danger of failure and dissolution (Sarasvathy, 2004) and there is a high failure rate due to such factors as poor sales, intense competition, lack of capital, lack of managerial abilities or capabilities and the enormous complexity of red tape (Cupido, 2002). The fear of bankruptcy is then believed to be a factor in the decision of many potential entrepreneurs not to start a business (Lundström \& Stevenson, 2005). Martins (2004) believes that fear of failure is kind of cultural and social barrier to entrepreneurship. Sandhu et al. (2011) show that Fear of failure has negative influence on entrepreneurial inclination of postgraduate students in Malaysia. Cost of bankruptcy is also another contributor to fear of failure and thus a barrier to entrepreneurship. Klapper et al. (2004) find that entry is higher in high entry industries in countries with lower cost of bankruptcy.

\subsection{Lack of Market Experience}

The capability to create a new business depends largely on previous education and work experience (Martins, 2004). Many entrepreneurs overlook their capabilities, expertise and acquired knowledge, and once they find the market of a particular industry potentially auspicious and opportune, just rush into that market without any associated experience and background. Lack of market knowledge and experience has been variously referred to as a barrier to entrepreneurship (Vesper, 1983; Qunlian, 2011; Low \& MacMillan, 1988). Harada (2003) shows that an entrepreneur's related business experience before start-up is positively related to the probability of success. Yusuf (1995) investigates a random sample of 220 South Pacific entrepreneurs, and finds that 30 percent of them had prior experience in their present line of business. Lundström and Stevenson (2005) claim that experience from working in a small business, and hands-on experience in starting and running an enterprise will contribute to the acquisition of entrepreneurial skills. Qunlian (2011) argues that because of lack of practice experience, graduates' entrepreneurship ability mainly comes from entrepreneurship education in the phase of higher education; however, the current development of entrepreneurship education cannot meet the market requirements of China. Van de Ven et al. (1984) find that entrepreneurship success is related to education and experience next to other factors. Vesper (1983) identifies 12 barriers to entrepreneurship one of which is lack of market knowledge.

\subsection{Employee Related Difficulties}

Labor force is one of the primary sources entrepreneurs need to run their venture. Obtaining qualified, motivated and willing to grow, employees and retaining them is a difficult task of entrepreneurs. This task becomes a barrier when employees' expectations increases, governmental regulations related to labor employment is hardened, and employee costs augments. Barth et al. (2006) refer to employee related difficulties as a barrier to entrepreneurship and argue that limitations in factors like cost of health, workers' compensation costs, locating qualified employees, social security taxes, keeping skilled employees, and health and safety regulations, contribute to this barrier. Aidis and Adachi (2007) refer to labor regulations as an institutional barrier to entry 
and exit in Russia, and argue that employers face regulatory difficulties in hiring and firing workers. They use World Bank indicators to show how difficult it is in Russia to hire a new worker, how rigid the regulations are on working hours, and how difficult it is to dismiss a redundant worker. Fairlie et al. (2010) focus on employer-based health insurance as a barrier to entrepreneurship. Employment regulation limits management flexibility and leads to smaller firm size and less research and development as well as less entrepreneurship growth (Martins, 2004).

\subsection{Lack of Adequate Entrepreneurship Training}

In order to foster the required skills the best floor is the educational system of the country. The performance of educational system on entrepreneurship has been investigated in different contexts (Qunlian, 2011; Sandhu et al., 2011; Khayri et al., 2011; Yaghoubi, 2010; Soysekerci \& Erturgut, 2010). Entrepreneurial skills and entrepreneurship must be taken as a basic goal in higher education (Qunlian, 2011) since education is important to provide the necessary technical and managerial skills for entrepreneurs (Humphrey, 2003). Reynolds et al. (1999) find that entrepreneurial capacity in the United Kingdom is depressed because a substantial majority of its citizens have inadequate skills and entrepreneurship education is significantly underdeveloped. Lundström and Stevenson (2005) find technical, business and entrepreneurial skills necessary and claim the acquisition of these skills could come through the education system. Yaghoubi (2010) regards insufficient attention to learning practical skills as a barrier to entrepreneurship in agricultural higher education of Iran. Qunlian (2011) believes entrepreneurship education plays a significant role in promoting graduates' entrepreneurship, and the entrepreneurship education course should be established as a public and compulsory course in colleges and universities. Indeed the greater a country's investment in tertiary education, the higher the rate of new firm formation (Reynolds et al., 1999). Lundström and Stevenson (2005) argue that appropriate education system and training programs are required for acquiring entrepreneurial skills and know-how.

\subsection{Aversion to Risk}

Another psychological barrier to entrepreneurship which is closely related to the barrier of fear of failure is aversion to risk. Indeed risk taking has very often been a phrase in many definitions of entrepreneurs. McClelland (1961) says entrepreneur is an energetic, moderate risk taker. Shapero's (Shapero, 1975) entrepreneur takes initiative, organizes some social-economic mechanisms, and accepts risk of failure. Timmons (1999) finds tolerance of risk as a desirable attitude and behavior of entrepreneurs. The literature suggests risk averse individuals rarely touch the concept of entrepreneurship. Cramer et al. (2002) empirically test and affirm the truism of the negative effect of risk aversion on entrepreneurship selection. Kihlstrom and Laffont (1979) find that less risk averse individuals set up in risky business, whilst more risk averse individuals took up more stable wage employment. Sandhu et al. (2011) regard lack of willingness to undertake risk as a barrier to entrepreneurship. Several more studies also report aversion to risk as a barrier to entrepreneurship (Cressy, 2000; Dickson \& Giglierano, 1986; Wang \& Wong, 2004; Newman, 2007).

\subsection{Lack of Appropriate Technical and Practical Skills}

Prior to any other entrepreneurial requirements, possessing technical and practical skills is an indispensable requisite. Indeed, owning some acquired skills, in many cases, will persuade individuals to pursue entrepreneurial initiatives (Reynolds et al., 1999) and lack of the appropriate skills and knowledge (Martins, 2004) will inhibit them. Lucas (1978) argues that all people are alike by their productivity as workers but they differ in terms of their entrepreneurial skills. Vesper (1983) also refers to lack of technical skills as a barrier to entrepreneurship. Onyebinama and Onyebinama (2010) find lack of skill in agricultural production, as one of the barriers to Nigerian agricultural entrepreneurship. Lazear (2004), however, takes an exaggerative view and claims entrepreneurs must be jacks-of-all-trades, and they need not be expert in any single skill, but they must be sufficiently good at a wide variety to make sure that the business does not fail. Baum et al. (2001) relax this view and just call for specific motivations and specific skills. Providing potential entrepreneurs with these skills needs adequate training programs. Lacking these required trainings is the next barrier.

\subsection{Lack of Entrepreneurial Capacity}

Even though, unsupportive environment is considered to be a barrier to entrepreneurship, in some supportive business contexts even, because of low level of entrepreneurial capacity, the rate of new firm entrance is inconsiderable. Lack of entrepreneurial capacity in a supportive environment, is like having oil wells in a land, but lacking the knowledge and workers who can mine these wells. Hence entrepreneurial capacity chiefly refers to the existence of people with entrepreneurship qualities, willingness and motivation to initiate new ventures, and generally a society which is greedy and voracious to success. Gnyawali and Fogel (1994) argue that entrepreneurship capacity is not only the ability and knowledge a person masters to create and manage a new 
business, but also socioeconomic conditions, such as public attitude toward entrepreneurship, successful role models, presence of experienced entrepreneurs, and diversity of economic activities, are very ascertaining. Reynolds et al. (1999) believe that capacity refers to the motivation of individuals to initiate new ventures and the extent to which they have the skills required to pursue entrepreneurial initiatives. They claim that the level of entrepreneurial activity is a function of the degree to which individuals realize entrepreneurial opportunities available and that they have the capacity - motivation and skills - to exploit them. Qunlian (2011) also thinks entrepreneurship capacity is the basic and sufficient condition of the implementation of entrepreneurship activities.

\subsection{Lack of Entrepreneurship Opportunities}

Entrepreneurship opportunity refers to both the existence and perception of market opportunities available for exploitation (Reynolds et al., 1999) and it is the possibility of creating new business and achieving success through the entrepreneur's effort (Qunlian, 2011). Gnyawali and Fogel (1994) define opportunity as the extent to which possibilities for new ventures exist and the extent to which entrepreneurs are able to influence their odds for success through their own actions. A profitable business opportunity is one of the four elements Vesper (1983) identifies in venture creation. Entrepreneurial opportunity allows those individuals who own an entrepreneurial "spirit" to go beyond any cultural boundaries (Acs \& Virgill, 2010). Many issues, from high rate of customer untouched needs, to high rate of unemployment in the society, could be seen as entrepreneurship opportunities. For example Sarasvathy (2004) sees low levels of unemployment as a barrier to entrepreneurship. Thus lack of entrepreneurship opportunities is considered as another barrier to entrepreneurship.

\subsection{Corrupted and Unsupportive Business Environment}

At the same time that existence of governmental severe regulations is considered to be a barrier to entrepreneurship, non-existence of governmental supportive and market-augmenting regulations will form another barrier. Qunlian (2011) argues that a good business environment is the basis for success in entrepreneurship and inappropriate entrepreneurship environment and non-existence of policy support systems are barriers for new business start-up. In order to develop entrepreneurship, essential facilities of public utilities and other elements of the business infrastructure are required (Dutz et al., 2000). Olson (2000) claims that it is not the lack of entrepreneurship that keeps underdeveloped countries backward, but it is the lack of market-augmenting governments. Aidis and Adachi (2007) show a full picture of an unsupportive business environment (i.e. Russia) and criticize lack of rule of law, inconsistent enforcement of regulations, and pervasive corruption. They argue that, in Russia, enforcement of laws occurs in a selective or arbitrary manner, there is no consistency or stability for firms to count on from the regulatory environment, friendly ties with government officials and bureaucrats are crucial in smoothing the way for businesses to operate, bribing is customary, and the business climate is especially hostile due to the predatory nature of many regulatory authorities and inspectors. Other institutional barriers such as lack of government assistance, infrastructure issues, poor contract and property laws and corruption has been variously mentioned (Ivy, 1997; Kiggundu, 2002; Chu et al., 2007; Benzing, Chu, \& Kara, 2009; Sandhu et al., 2011).

\subsection{Shortage of Funds and Resources}

One of the most cited barriers to entrepreneurship is financing difficulty in entrepreneurship. Many entrepreneurs have to give up their dream of new firm initiation in the face of financial problems. Utilizing entrepreneurial opportunities is more possible when people have greater financial capital (Evans \& L., 1989; Hurst \& Lusardi, 2004). Ramayah and Harun (2005) argue that capital access is one of the most difficult barriers to the growth of entrepreneurship. Qunlian (2011) finds shortage of funds and entrepreneurship capital as a major barrier to current university graduates' entrepreneurship in China. Sandhu et al. (2011) consider lack of resources, funds, and government assistance, as entrepreneurship barriers among Malaysian postgraduate students. Klapper et al. (2004) identify entry costs, private credit, access to finance, and human capital, as some barriers to entrepreneurship. Gable et al. (1995) who study entry barriers in retailing, recognize capital requirement, availability of store locations, and availability of qualified personnel as major entry barriers. Low and MacMillan (1988) name shortage of funds and resources, lack of "seed money". In some cases, shortage of funds and resources could be compensated for, with obtaining loans; however, inability to acquire finance is known to be another barrier to entrepreneurship (Cupido, 2002). Martins (2004) refers to economic and financial barriers, and argues that many entrepreneurs don't have bank credit and have several difficulties in getting loans. 


\section{Modeling the Interactions among the Barriers to Entrepreneurship}

\subsection{Interpretive Structural Modeling (ISM)}

Interpretive Structural Modeling (ISM), provides an ordered and directional framework for complex problems, and gives decision makers a realistic and clear picture of the system and its involved variables (Wang et al., 2008; Chandramowli et al., 2011). This method is interpretive since the group's judgment decides whether and how items are related; it is structural because it extracts an overall structure from the complex set of items, based on the identified relationships; and it is modeling in that it provides a digraph model of the specific relationships and the overall structure (Mandal \& Deshmukh, 1994). ISM was introduced by Warfield (1974) as a suitable modeling technique for analyzing the impact of one element on other elements and for getting better insights into the problem (Wang et la., 2008).

ISM has been adopted in different domains of science, and for various aims, however, it has been more appreciated as an appealing method for giving structure to complex interactions among barriers that impede the success of the system. Wang et al. (2008) utilize ISM to investigate the interactions among the major barriers which prevent the practice of energy saving in China. Talib et al. (2011) employ ISM to analyze the interactions among the barriers to total quality management (TQM) implementation. Singh and Kant (2008) identify barriers to knowledge management and make use of ISM to develop the relationships among these barriers. Chandramowli et al. (2011) adopt ISM for the analysis of barriers to development in landfill communities. Hence we also use ISM to analyze the interactions among the barriers to entrepreneurship.

We present the steps of constructing the ISM steps with reference to the works of (Thakkar et al., 2008; Wang et al., 2008; Singh \& Kant, 2008) as follows:

Step 1: Identify and list all the related elements, factors, criteria, or dimensions of the system (here barriers).

Step 2: Form a contextual relationship between elements with respect to which pairs of elements would be examined.

Step 3: Develop the Structural Self-Interaction Matrix (SSIM) for elements, which indicates pair-wise relationships among elements of the system.

Step 4: Develop the binary initial reachability matrix (IRM) from SSIM and check it for transitivity. The transitivity of the contextual relation is a fundamental assumption made in ISM that states if an element $A$ is related to $B$ and $B$ is related to $C$, then $A$ is necessarily related to $C$.

Step 5: Partition the IRM into different levels.

Step 6: Construct a directed graph based on the relationships given in the IRM, however remove the transitive links.

Step 7: Convert the resultant graph to an ISM-based model by replacing element nodes with the statements.

Step 8: Review the model to check for conceptual inconsistency and make the necessary modifications.

The steps of ISM which lead to model construction for the interactions among barriers to entrepreneurship are applied in the following subsections.

\subsection{Structural Self-Interaction Matrix (SSIM)}

In order to identify the nature of contextual relationships among the barriers, we initially got help from a group of 7 experts. Another group of three was also used in the final step of ISM approach. All these experts had both considerable academic background and comprehensive practical personal experience with entrepreneurship. Two general discussion meetings were held, with a three-week interval to make sure about the consistency of their views. In each session, they were asked to perform a contextual connection of "leads to" type between any two barriers. That is, when barrier $i$ leads to barrier $j$, this barrier will help barrier $j$ to happen, or will reinforce it.

All relationships between any two barriers $i$ and $j$ and the associated direction of the relations were questioned. Four symbols, i.e. $V, A, X$ and $O$ were used to imply the type of relationship between the barriers $i$ and $j$ as follows:

$V$ - Barrier $i$ will lead to barrier $j$;

$A$ - Barrier $j$ will lead to barrier $i$;

$X$ - Barriers $i$ and $j$ will lead to each other; and

$O$ - Barriers $i$ and $j$ are unrelated. 
The contextual relationships among the barriers to entrepreneurship were identified by the experts group as in Table 1. For example, the group believed that Lack of adequate entrepreneurship training, will lead to Lack of appropriate technical and practical skills.

Table 1. Structural self-interaction matrix (SSIM)

\begin{tabular}{clllllllllll}
\hline Barrier No. & \multicolumn{1}{c}{ Barrier description } & $\mathbf{1 1}$ & $\mathbf{1 0}$ & $\mathbf{9}$ & $\mathbf{8}$ & $\mathbf{7}$ & $\mathbf{6}$ & $\mathbf{5}$ & $\mathbf{4}$ & $\mathbf{3}$ & $\mathbf{2}$ \\
\hline $\mathbf{1}$ & Market entry severe regulations & O & A & V & V & O & V & O & X & O & V \\
$\mathbf{2}$ & Fear of failure & A & A & A & O & A & V & A & A & A & - \\
$\mathbf{3}$ & Lack of market experience & O & A & O & A & X & V & A & A & - & \\
$\mathbf{4}$ & Employee related difficulties & X & A & O & V & V & V & V & - & & \\
$\mathbf{5}$ & Lack of adequate entrepreneurship training & A & A & A & A & V & V & - & & & \\
$\mathbf{6}$ & Aversion to risk & A & A & O & O & A & - & & & \\
$\mathbf{7}$ & Lack of appropriate technical and practical skills & O & O & A & A & - & & & & \\
$\mathbf{8}$ & Lack of entrepreneurial capacity & A & A & A & - & & & & \\
$\mathbf{9}$ & Lack of entrepreneurship opportunities & A & A & - & & & & & & \\
$\mathbf{1 0}$ & Corrupted and unsupportive business environment & O & - & & & & & & & &
\end{tabular}

\subsection{Initial Reachability Matrix (IRM)}

Now we develop the binary matrix of initial reachability based on SSIM, by substituting $V, A, X$, and $O$, by 1 and 0 according to the following rules:

If the $(i, j)$ entry in the SSIM is $V$, the $(i, j)$ entry in the IRM becomes 1 and the $(j, i)$ entry becomes 0 ;

If the $(i, j)$ entry in the SSIM is $A$, the $(i, j)$ entry in the IRM becomes 0 and the $(j, i)$ entry becomes 1 ;

If the $(i, j)$ entry in the SSIM is $X$, both the $(i, j)$ entry and the $(j, i)$ entry in the IRM become 1 ;

And If the $(i, j)$ entry in the SSIM is $O$, both the $(i, j)$ and $(j, i)$ entry in the IRM become 0 . Moreover for $(i, j)$ entry in IRM where $i=j$, the entry is considered to be 1 .

The IRM for barriers to entrepreneurship is shown in Table 2.

Table 2. Initial reachability matrix (IRM)

\begin{tabular}{ccccccccccccc}
\hline Barriers & $\mathbf{1}$ & $\mathbf{2}$ & $\mathbf{3}$ & $\mathbf{4}$ & $\mathbf{5}$ & $\mathbf{6}$ & $\mathbf{7}$ & $\mathbf{8}$ & $\mathbf{9}$ & $\mathbf{1 0}$ & $\mathbf{1 1}$ \\
\hline $\mathbf{1}$ & 1 & 1 & 0 & 1 & 0 & 1 & 0 & 1 & 1 & 0 & 0 \\
$\mathbf{2}$ & 0 & 1 & 0 & 0 & 0 & 1 & 0 & 0 & 0 & 0 & 0 \\
$\mathbf{3}$ & 0 & 1 & 1 & 0 & 0 & 1 & 1 & 0 & 0 & 0 & 0 \\
$\mathbf{4}$ & 1 & 1 & 1 & 1 & 1 & 1 & 1 & 1 & 0 & 0 & 1 \\
$\mathbf{5}$ & 0 & 1 & 1 & 0 & 1 & 1 & 1 & 0 & 0 & 0 & 0 \\
$\mathbf{6}$ & 0 & 0 & 0 & 0 & 0 & 1 & 0 & 0 & 0 & 0 & 0 \\
$\mathbf{7}$ & 0 & 1 & 1 & 0 & 0 & 1 & 1 & 0 & 0 & 0 & 0 \\
$\mathbf{8}$ & 0 & 0 & 1 & 0 & 1 & 0 & 1 & 1 & 0 & 0 & 0 \\
$\mathbf{9}$ & 0 & 1 & 0 & 0 & 1 & 0 & 1 & 1 & 1 & 0 & 0 \\
$\mathbf{1 0}$ & 1 & 1 & 1 & 1 & 1 & 1 & 0 & 1 & 1 & 1 & 0 \\
$\mathbf{1 1}$ & 0 & 1 & 0 & 1 & 1 & 1 & 0 & 1 & 1 & 0 & 1 \\
\hline
\end{tabular}

In order to construct the final reachability matrix (FRM), however, the transitivity effects in IRM should be considered. For example in the IRM (Table 2), 1 leads to 4 and 4 leads to 11 , thus 1 also leads to 11 . The final reachability matrix is presented in Table 3 . The driving power and dependence of each barrier are also presented in this table. The driving power of one barrier is the total number of barriers (including itself) that this barrier leads to. The dependence of one barrier is the total number of barriers (including itself) that can lead to this barrier. These data are later needed for constructing the clustering diagram. 
Table 3. Final reachability matrix (FRM)

\begin{tabular}{ccccccccccccc}
\hline Barriers & $\mathbf{1}$ & $\mathbf{2}$ & $\mathbf{3}$ & $\mathbf{4}$ & $\mathbf{5}$ & $\mathbf{6}$ & $\mathbf{7}$ & $\mathbf{8}$ & $\mathbf{9}$ & $\mathbf{1 0}$ & $\mathbf{1 1}$ & Driving power \\
\hline $\mathbf{1}$ & 1 & 1 & 1 & 1 & 1 & 1 & 1 & 1 & 1 & 0 & 1 & $\mathbf{1 0}$ \\
$\mathbf{2}$ & 0 & 1 & 0 & 0 & 0 & 1 & 0 & 0 & 0 & 0 & 0 & $\mathbf{2}$ \\
$\mathbf{3}$ & 0 & 1 & 1 & 0 & 0 & 1 & 1 & 0 & 0 & 0 & 0 & $\mathbf{4}$ \\
$\mathbf{4}$ & 1 & 1 & 1 & 1 & 1 & 1 & 1 & 1 & 1 & 0 & 1 & $\mathbf{1 0}$ \\
$\mathbf{5}$ & 0 & 1 & 1 & 0 & 1 & 1 & 1 & 0 & 0 & 0 & 0 & $\mathbf{5}$ \\
$\mathbf{6}$ & 0 & 0 & 0 & 0 & 0 & 1 & 0 & 0 & 0 & 0 & 0 & $\mathbf{1}$ \\
$\mathbf{7}$ & 0 & 1 & 1 & 0 & 0 & 1 & 1 & 0 & 0 & 0 & 0 & $\mathbf{4}$ \\
$\mathbf{8}$ & 0 & 1 & 1 & 0 & 1 & 1 & 1 & 1 & 0 & 0 & 0 & $\mathbf{6}$ \\
$\mathbf{9}$ & 0 & 1 & 1 & 0 & 1 & 1 & 1 & 1 & 1 & 0 & 0 & $\mathbf{7}$ \\
$\mathbf{1 0}$ & 1 & 1 & 1 & 1 & 1 & 1 & 1 & 1 & 1 & 1 & 1 & $\mathbf{1 1}$ \\
$\mathbf{1 1}$ & 1 & 1 & 1 & 1 & 1 & 1 & 1 & 1 & 1 & 0 & 1 & $\mathbf{1 0}$ \\
Dependence & $\mathbf{4}$ & $\mathbf{1 0}$ & $\mathbf{9}$ & $\mathbf{4}$ & $\mathbf{7}$ & $\mathbf{1 1}$ & $\mathbf{9}$ & $\mathbf{6}$ & $\mathbf{5}$ & $\mathbf{1}$ & $\mathbf{4}$ & \\
\hline
\end{tabular}

\subsection{Level Partitions}

In this step the reachability and antecedent set for each barrier is found using the FRM. The reachability set includes the element itself and the other elements which it can lead to. The antecedent set includes the element itself and the other elements which can lead to this barrier. Another column is also dedicated to the intersection of reachability and antecedent set of each barrier. The construction of ISM diagraph starts from here.

The barrier(s) which has (have) a common reachability set and intersection is (are) considered as the top level element(s) in the diagraph. This element (or these elements) will lead to no other elements. In the next step the top level barrier(s) is (are) omitted from the list and its (their) corresponding number(s) is (are) removed from all reachability, antecedent, or intersection sets. This will help to ascertain the next level barrier. The same procedure is continued until the levels of all the barriers are determined. Level partitioning procedure for barriers to entrepreneurship, is presented through Table 4 to Table 10.

As it is clear from Table 4, the reachability set for the 6th barrier is same as its intersection set and thus this barrier is placed at the top of the diagraph as the first level.

Table 4. First level partitioning of the reachability matrix

\begin{tabular}{|c|c|c|c|c|}
\hline Barrier No. & Reachability Set & Antecedent Set & Intersection & Level \\
\hline 1 & $1,2,3,4,5,6,7,8,9,11$ & $1,4,10,11$ & $1,4,11$ & \\
\hline 2 & 2,6 & $1,2,3,4,5,7,8,9,10,11$ & 2 & \\
\hline 3 & $2,3,6,7$ & $1,3,4,5,7,8,9,10,11$ & 3,7 & \\
\hline 4 & $1,2,3,4,5,6,7,8,9,11$ & $1,4,10,11$ & $1,4,11$ & \\
\hline 5 & $2,3,5,6,7$ & $1,4,5,8,9,10,11$ & 5 & \\
\hline 6 & 6 & $1,2,3,4,5,6,7,8,9,10,11$ & 6 & I \\
\hline 7 & $2,3,6,7$ & $1,3,4,5,7,8,9,10,11$ & 3,7 & \\
\hline 8 & $2,3,5,6,7,8$ & $1,4,8,9,10,11$ & 8 & \\
\hline 9 & $2,3,5,6,7,8,9$ & $1,4,9,10,11$ & 9 & \\
\hline 10 & $1,2,3,4,5,6,7,8,9,10,11$ & 10 & 10 & \\
\hline 11 & $1,2,3,4,5,6,7,8,9,11$ & $1,4,10,11$ & $1,4,11$ & \\
\hline
\end{tabular}

Removing the sixth barrier from the rows, and omitting its corresponding number in all the sets, Table 5 is achieved, in which the second barrier is only qualified to be located in the second level. 
Table 5. Second level partitioning of the reachability matrix

\begin{tabular}{cllll}
\hline Barrier No. & Reachability Set & Antecedent Set & Intersection & Level \\
\hline $\mathbf{1}$ & $1,2,3,4,5,7,8,9,11$ & $1,4,10,11$ & $1,4,11$ \\
$\mathbf{2}$ & 2 & $1,2,3,4,5,7,8,9,10,11$ & 2 & II \\
$\mathbf{3}$ & $2,3,7$ & $1,3,4,5,7,8,9,10,11$ & 3,7 \\
$\mathbf{4}$ & $1,2,3,4,5,7,8,9,11$ & $1,4,10,11$ & $1,4,11$ \\
$\mathbf{5}$ & $2,3,5,7$ & $1,4,5,8,9,10,11$ & 5 \\
$\mathbf{7}$ & $2,3,7$ & $1,3,4,5,7,8,9,10,11$ & 3,7 \\
$\mathbf{8}$ & $2,3,5,7,8$ & $1,4,8,9,10,11$ & 8 \\
$\mathbf{9}$ & $2,3,5,7,8,9$ & $1,4,9,10,11$ & 9 \\
$\mathbf{1 0}$ & $1,2,3,4,5,7,8,9,10,11$ & 10 & 10 \\
$\mathbf{1 1}$ & $1,2,3,4,5,7,8,9,11$ & $1,4,10,11$ & $1,4,11$ \\
\hline
\end{tabular}

The same approach continues (Table 6 to 10) until all the barriers are classified into their assigned level.

Table 6. Third level partitioning of the reachability matrix

\begin{tabular}{cllll}
\hline Barrier No. & Reachability Set & Antecedent Set & Intersection & Level \\
\hline $\mathbf{1}$ & $1,5,7,8,9,10,11$ & 1 & 1 & \\
$\mathbf{3}$ & 3 & $3,4,5,8,9,10$ & 4 & III \\
$\mathbf{4}$ & $3,4,5,7,8,9,10,11$ & 4 & $5,7,8,9,10$ & III \\
$\mathbf{5}$ & $3,5,7,8,9,10$ & $1,4,5,7,8,9,10$ & $5,7,8,9$ & $7,8,9$ \\
$\mathbf{7}$ & $5,7,8,9$ & $1,4,5,7,8,9,10,11$ & $5,7,8,9,10$ \\
$\mathbf{8}$ & $3,5,7,8,9$ & $1,4,5,7,8,9,10$ & $5,9,10$ \\
$\mathbf{9}$ & $3,5,7,8,9,10$ & $1,4,5,7,8,9,10,11$ & 11 \\
$\mathbf{1 0}$ & $3,5,7,8,9,10$ & $1,4,5,9,10$ & $1,4,11$ & \\
\hline
\end{tabular}

Table 7. Fourth level partitioning of the reachability matrix

\begin{tabular}{cllll}
\hline Barrier No. & Reachability Set & Antecedent Set & Intersection & Level \\
\hline $\mathbf{1}$ & $1,4,5,8,9,11$ & $1,4,10,11$ & $1,4,11$ \\
$\mathbf{4}$ & $1,4,5,8,9,11$ & $1,4,10,11$ & $1,4,11$ \\
$\mathbf{5}$ & 5 & $1,4,5,8,9,10,11$ & 5 & IV \\
$\mathbf{8}$ & 5,8 & $1,4,8,9,10,11$ & 8 & 9 \\
$\mathbf{9}$ & $5,8,9$ & $1,4,9,10,11$ & 10 \\
$\mathbf{1 0}$ & $1,4,5,8,9,10,11$ & 10 & $1,4,11$ \\
$\mathbf{1 1}$ & $1,4,5,8,9,11$ & $1,4,10,11$ & \\
\hline
\end{tabular}

Table 8. Fifth level partitioning of the reachability matrix

\begin{tabular}{cllll}
\hline Barrier No. & Reachability Set & Antecedent Set & Intersection & Level \\
\hline $\mathbf{1}$ & $1,4,8,9,11$ & $1,4,10,11$ & $1,4,11$ \\
$\mathbf{4}$ & $1,4,8,9,11$ & $1,4,10,11$ & $1,4,11$ \\
$\mathbf{8}$ & 8 & $1,4,8,9,10,11$ & 8 & $\mathrm{~V}$ \\
$\mathbf{9}$ & 8,9 & $1,4,9,10,11$ & 9 & 10 \\
$\mathbf{1 0}$ & $1,4,8,9,10,11$ & 10 & $1,4,11$ \\
$\mathbf{1 1}$ & $1,4,8,9,11$ & $1,4,10,11$ & \\
\hline
\end{tabular}


Table 9. Sixth level partitioning of the reachability matrix

\begin{tabular}{cllll}
\hline Barrier No. & Reachability Set & Antecedent Set & Intersection & Level \\
\hline $\mathbf{1}$ & $1,4,9,11$ & $1,4,10,11$ & $1,4,11$ & \\
$\mathbf{4}$ & $1,4,9,11$ & $1,4,10,11$ & $1,4,11$ & VI \\
$\mathbf{9}$ & 9 & $1,4,9,10,11$ & 9 & 10 \\
$\mathbf{1 0}$ & $1,4,9,10,11$ & 10 & $1,4,11$ & \\
$\mathbf{1 1}$ & $1,4,9,11$ & $1,4,10,11$ & & \\
\hline
\end{tabular}

Table 10. Seventh and eighth level partitioning of the reachability matrix

\begin{tabular}{clllc}
\hline Barrier No. & Reachability Set & Antecedent Set & Intersection & Level \\
\hline $\mathbf{1}$ & $1,4,11$ & $1,4,10,11$ & $1,4,11$ & VII \\
$\mathbf{4}$ & $1,4,11$ & $1,4,10,11$ & $1,4,11$ & VII \\
$\mathbf{1 0}$ & $1,4,10,11$ & 10 & 10 & VIII \\
$\mathbf{1 1}$ & $1,4,11$ & $1,4,10,11$ & $1,4,11$ & VII \\
\hline
\end{tabular}

\subsection{Formation of ISM-Based Model}

Determining the levels of elements in the digraph through step 4, and having the initial reachability matrix (IRM), the initial ISM digraph could be established. To do so, after positioning the elements into their designated levels, the IRM is utilized to determine whether an arrow goes from the $i$ th element to the $j$ th element, or not. And ultimately, after removing the transitivities the final ISM digraph is obtained as in Figure 1.

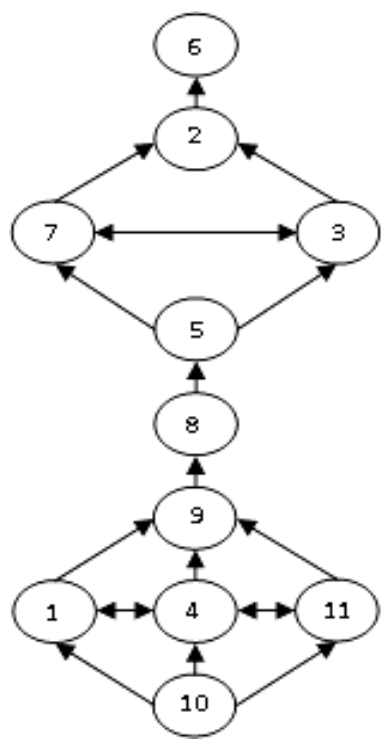

Figure 1. ISM-based model for interactions among the elements

As it is depicted in the ISM-based model of Fig 1, element 6 goes to the top of the hierarchy as also Table 4 assigns the first level to this element. Element 2 is on the next level and so on. Starting from the bottom of the hierarchical structure in Fig 1, it could be seen that according to the SSIM there are links from 10 to 1, 4, and 11. There are also links from 1 to 4 and vice versa, and from 4 to 11 and vice versa, but as suggested by SSIM there is no link from 1 to 11. The rest of the digraph could be explained likewise. In order to construct the final structural model of interactions among barriers to entrepreneurship, these elements should be replaced by related statements (Figure 3). 


\subsection{Clustering of Barriers}

Using Table 3, with regard to barriers' dependence and driving powers, barriers could be classified into 4 distinct clusters, i.e. autonomous barriers, dependent barriers, linkage barriers, and independent barriers.

The first cluster (I) consists of autonomous barriers that have weak driving power and weak dependence, and are relatively disconnected from the system. As they get more distant from the corner they are more interactive with the system. The second cluster (II) contains dependent barriers that have weak driving power but strong dependence. They are more affected by other barriers rather than affecting them. The third cluster (III) contains linkage barriers which own strong driving powers along with strong dependence. These barriers are central to system and any action of these barriers will have an effect on others and also have a feedback on themselves. The barriers of the fourth cluster (IV) are independent barriers which have strong driving power but weak dependence. They are the basis on which many other barriers are reinforced, and call for special attention.

With respect to Table 3, barriers to entrepreneurship are placed in their corresponding positions in the clustering diagram (Fig 2). For example barrier 9, has driving power of 7 and dependence of 5, hence it is located in the related position as an independent barrier. Barriers to entrepreneurship are divided into two groups according to the clustering diagram, i.e. dependent and independent barriers ( 8 is actually central), and there are no linkage or autonomous barriers in the system. Barriers 1, 4, 11, 9, and 10, are then, independent barriers and barriers 5, 3, 7, 2 , and 6 are dependent barriers. Barrier 8 is central.

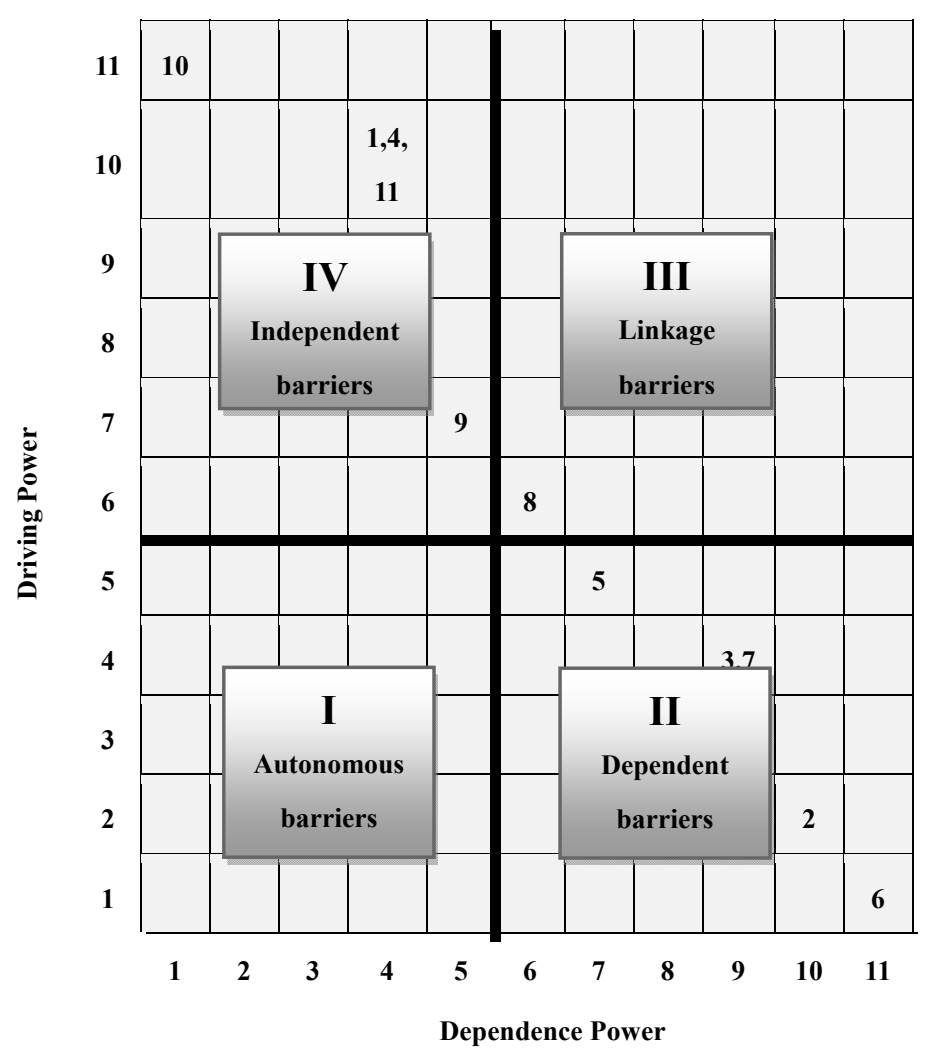

Figure 2. Clustering diagram

\section{Analysis of the ISM-Based Model}

Replacing the barriers labels with corresponding statements in Fig 1, the final ISM-based model for barriers to entrepreneurship could be achieved as in Fig 3. This model was presented at a committee of three experts (discussed earlier) who were dependent from the first group of 5 experts who were engaged in ISM construction steps. All the members agreed on the consistency of the model with real world variables, their own professional and academic experience, and the axiomatic rationale of the interactions among barriers to entrepreneurship.

Indeed, this structural model provides many fruitful and informative connotations, which can greatly aid decision makers and entrepreneurs. 
As was discussed earlier in the course of the paper, risk taking is one of the major elements in the available definitions of entrepreneurs (McClelland, 1961; Shapero, 1975; Timmons, 1999; Kihlstrom \& Laffont, 1979; Cramer, Hartog, Jonker, \& Van Praag, 2002), and entrepreneurship goes hand in hand with risk taking. Risk averse individuals undeniably would not make good entrepreneurs. Moreover, risk aversion is a psychological barrier to entrepreneurship (Sandhu, Sidique, \& Riaz, 2011). Thus, at the first glance it may seem that, this barrier is an inside barrier and solely related to personal nature of entrepreneurs. However, the findings of our model suggest that aversion to risk, originally emanates from structural and institutional barriers to entrepreneurship. That is, in an unsupportive and corrupted business environment, more aversion to risk is expected.

People are aversive to the risk of launching new business, because of the fear of failure. Thus, as the model also suggests, fear of failure leads to aversion to risk. There is a positive relationship between lack of appropriate technical and practical skills and market experience, and fear of failure. The probability of failure is much larger for individuals who take part in activities, which they have insufficient knowledge and experience about. The mental logic of human being mind also realizes this trade off and as the individual is informed about his/her weakness in required experience and knowledge for the chosen business, understands the existing probability of failure and hence refuses to take the risk.

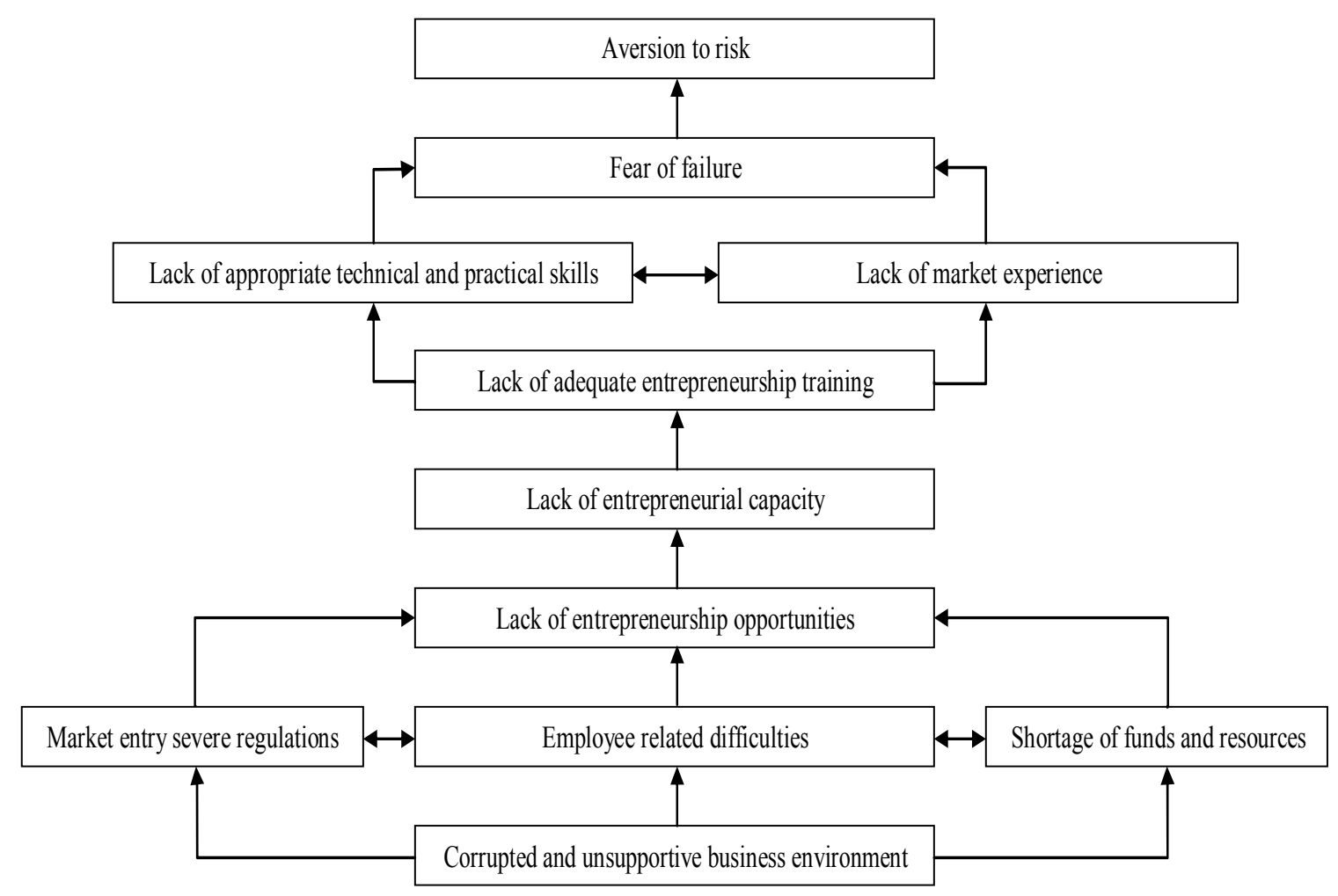

Figure 3. ISM-based model for barriers to entrepreneurship

Indeed, this structural model provides many fruitful and informative connotations, which can greatly aid decision makers and entrepreneurs.

As was discussed earlier in the course of the paper, risk taking is one of the major elements in the available definitions of entrepreneurs (McClelland, 1961; Shapero, 1975; Timmons, 1999; Kihlstrom \& Laffont, 1979; Cramer, Hartog, Jonker, \& Van Praag, 2002), and entrepreneurship goes hand in hand with risk taking. Risk averse individuals undeniably would not make good entrepreneurs. Moreover, risk aversion is a psychological barrier to entrepreneurship (Sandhu, Sidique, \& Riaz, 2011). Thus, at the first glance it may seem that, this barrier is an inside barrier and solely related to personal nature of entrepreneurs. However, the findings of our model suggest that aversion to risk, originally emanates from structural and institutional barriers to entrepreneurship. That is, in an unsupportive and corrupted business environment, more aversion to risk is expected. 
People are aversive to the risk of launching new business, because of the fear of failure. Thus, as the model also suggests, fear of failure leads to aversion to risk. There is a positive relationship between lack of appropriate technical and practical skills and market experience, and fear of failure. The probability of failure is much larger for individuals who take part in activities, which they have insufficient knowledge and experience about. The mental logic of human being mind also realizes this trade off and as the individual is informed about his/her weakness in required experience and knowledge for the chosen business, understands the existing probability of failure and hence refuses to take the risk.

Lack of appropriate technical and practical skills and market experience then, directly originates from the weakness of the existing educational system in the business environment. Many studies have investigated the role of the educational system in fostering entrepreneurial skills and experience (Qunlian, 2011; Sandhu, Sidique, \& Riaz, 2011; Khayri, Yaghoubi, \& Yazdanpanah, 2011; Yaghoubi, 2010; Soysekerci \& Erturgut, 2010). Entrepreneurship education should be implemented in universities and colleges, entrepreneurship and know about business (KAB) courses should become compulsory, teaching methods should be revised and more practical training opportunities should be provided in order to supply trainees with the required skills and experience (Qunlian, 2011).

Moreover, regarding the ISM model, it could be grasped that Lack of appropriate technical and practical skills, and Lack of market experience, comes both from Lack of adequate entrepreneurship training, and from each other. In other words, although weak educational system and training programs which lack both appropriate technical and practical plans will not enrich trainees with the required skills and experience, it is not the sole source of acquiring the needed skills and experience, and skills and experience themselves also affect one another. Working for a long time in a specific market, even without related academic knowledge and skills, may lead to acquiring the same skills and knowledge, however, at the cost of experiencing several times of failure. In an inverse way, individuals with the required technical and practical skills, have a better learning quality and will obtain the needed market experience in a short time. Thus, next to the lack of entrepreneurial training programs, that lead to lack of appropriate technical and practical skills, Lack of market experience, may as well lead to lack of appropriate technical and practical skills (and vice versa).

The ISM-based model for barriers to entrepreneurship suggests that lack of entrepreneurial capacity leads to lack of entrepreneurship training. Indeed this seems to be completely true. Providing high quality training programs for a society which is incapable of entrepreneurial qualities is like providing first class singing courses for a group of deaf and dumb people. Hence lack of entrepreneurial capacity will frustrate the institutional and governmental motivation to improve the entrepreneurship training programs.

But what leads to lack of entrepreneurial capacity? In fact when there is no race, you will not practice. When people in a socioeconomic system feel no winning and attractive opportunities and find no possibility of creating new business, their willingness, motivation and attraction to entrepreneurship will be hampered and thus general entrepreneurial capacity of the society will gradually decline.

Finally, corrupted and unsupportive business environment will lead to the barriers of employee related difficulties, Market entry severe regulations, and Shortage of funds and resources, which are all the foundations of the hierarchical of our ISM model. In a corrupted and unsupportive business environment, rules and regulations are articulated in an entrepreneurship exhausting manner. These regulations are too severe and cause too many severe obstacles including employee related ones. Entrepreneurs will experience difficulties in hiring labor force, in keeping them, and in firing them. They will easily lose their funds and resources due to the corruptness of the business environment and the unsupportive nature of this environment will not help entrepreneurs in obtaining financial resources, and passes severe regulations that disappoint them from obtaining a loan. All these will then exhaust and destruct all possible entrepreneurial opportunities.

Overall, we can divide the barriers in the model into two major groups of "inside" and "outside" barriers. Inside barriers (i.e. fear of failure, lack of market experience, aversion to risk, and lack of appropriate technical and practical skills) occupy the top levels of the hierarchical model. We call them inside barriers because they are entrepreneurs-related (or inside the entrepreneurs) and they refer to personal weaknesses of individuals. As Fig 2, also suggests all these inside barriers are dependent barriers. On the other hand, outside barriers (i.e. market entry severe regulations, employee related difficulties, lack of adequate entrepreneurship training, lack of entrepreneurial capacity, lack of entrepreneurship opportunities, corrupted and unsupportive business environment, shortage of funds and resources; however shortage of funds and resources could also be regarded as an inside barrier) occupy the foundations of the model and they are more independent barriers. Simply put, we can conclude inside barriers are very often brought about by outside barriers. This suggest that entrepreneur 
is not always the one to be blamed for lacking entrepreneurial qualities, but the infrastructural situations, institutional and governmental structure which are inadequate and feeble in fostering entrepreneurship, are to be blamed.

\section{Discussion and Conclusion}

Entrepreneurship is the key to development and job formation, and well accounts for the crisis of unemployment. It is much praised and is very important to societies and governments, however it has not received the practical attention it deserves, and not enough attempts has been made in order to identify and remove obstacles in the way of entrepreneurs. Indeed, various barriers impede entrepreneurial activities. These barriers have been sparsely and case dependently reported in the literature, but, to the best of our knowledge, no particular study has investigated general barriers to entrepreneurship.

In this paper, after a rigorous review on the most relevant and available literature, we tried to bridge the existing gap by identifying 11 major barriers to entrepreneurship, and we presented the literature support for them. The barriers we identified include market entry severe regulations, fear of failure, lack of market experience, employee related difficulties, lack of adequate entrepreneurship training, aversion to risk, lack of appropriate technical and practical skills, lack of entrepreneurial capacity, lack of entrepreneurship opportunities, corrupted and unsupportive business environment, shortage of funds and resources.

Since we believed that these barriers are not completely stand-alone and they have active interactions with each other we employed interpretive structural modeling (ISM) approach to analyze the interactions among these barriers. We used experts' views to put forth the steps of ISM approach and finally we arrived at the structural model of Figure 3. This model and the implications of the clustering diagram leaded us to some understanding about the interactions among the barriers to entrepreneurship.

We argue that barriers to entrepreneurship are whether inside barriers or outside barriers. Inside barriers are inside the entrepreneur himself / herself and they impede the individual to touch the concept of entrepreneurship from inside not outside. Inside barriers include aversion to risk, lack of appropriate technical and practical skills fear of failure, and lack of market experience. On the other hand, outside barriers are outside the entrepreneur reach and they are posed by the outside resources. These barriers include market entry severe regulations, employee related difficulties, lack of adequate entrepreneurship training, lack of entrepreneurial capacity, lack of entrepreneurship opportunities, corrupted and unsupportive business environment, and shortage of funds and resources. However, shortage of funds and resources could be also seen as an inside barrier from another point of view.

With an inexperienced first look, inside barriers seem to be completely personal and they may be seen as obvious required requisites possessed by entrepreneurs. However, the ISM-based model and the clustering diagram prove this false. All of these barriers are dependent barrier; dependent on outside barriers. Outside barriers are the institutional, structural and governmental barriers which lead to inside barriers. They are the foundations of the hierarchical of the ISM-model and the drivers of the system of interactive barriers, which finally lead individuals to averse the risk of launching a new business.

We find that most of the barriers to entrepreneurship emanate from the corrupted and unsupportive business environment. This unfavorable environment, poses difficult rules and regulations, exhausts entrepreneurs' funds and resources and kills the entrepreneurial opportunities and capacities. When this happens, the necessity of providing a qualified educational system which can supply individuals with required skills and experience is eliminated. These individuals, who are now aware of their lack of skills and experience, are frightened to take risk and end up in failure.

Thus the key to develop entrepreneurship is still in the hand of top governmental management. The business environment should be improved, more supporting rules and regulations should be passed, redundant and bothering bureaucratic procedures should be reduced to minimum, obtaining loans should be facilitated, and employees are employed easier. Then we can expect a flourished society with rich business opportunities and high entrepreneurial capacity. Individuals will find too many success benchmarks around them, and go for the needed skills and abilities to start their own business.

\section{References}

Acs, Z. J., \& Virgill, N. (2010). Entrepreneurship in Developing Countries. International Handbook Series on Entrepreneurship, 5, 485-515. http://dx.doi.org/10.1007/978-1-4419-1191-9_18

Aidis, R., \& Adachi, Y. (2007). Russia: Firm entry and survival barriers. Economic Systems, 31, 391-411. http://dx.doi.org/10.1016/j.ecosys.2007.08.003 
Audretsch, D. B. (1995). Innovation, growth and survival. International Journal of Industrial Organization, 13, 441-457. http://dx.doi.org/10.1016/0167-7187(95)00499-8

Barth, J. R., Yago, G., \& Zeidman, B. (2006). Barriers to Entrepreneurship in Emerging Domestic Markets: Analysis and Recommendations. Milken Institute.

Baum, J. R., Locke, E., \& Smith, K. (2001). A multidimensional model of venture growth. Academy of Management Journal, 44, 292-303. http://dx.doi.org/10.2307/3069456

Baumol, W. (1990). Entrepreneurship: productive, unproductive, and destructive. Journal of Political Economy, 98 , 893-921. http://dx.doi.org/10.1086/261712

Bemstein, A. (2000). Entrepreneurs' development: red tape strangles entrepreneurs. Finance Week, 37-38.

Benzing, C., Chu, H. M., \& Kara, O. (2009). Entrepreneurs in Turkey: a factor analysis of motivations, success factors and problems. Journal of Small Business Management, 47, 58-91. http://dx.doi.org/10.1111/j.1540-627X.2008.00262.x

Chandramowli, S., Transue, M., \& Felder, F. A. (2011). Analysis of barriers to development in landfill communities using interpretive structural modeling. Habitat International, 35, 246-253. http://dx.doi.org/10.1016/j.habitatint.2010.09.005

Chu, H. M., Benzing, C., \& McGee, C. (2007). Ghanaian and Kenyan entrepreneurs: a comparative analysis of their motivations, success characteristics, and problems. Journal of Developmental Entrepreneurship, 12, 295-322. http://dx.doi.org/10.1142/S1084946707000691

Cramer, J. S., Hartog, J., Jonker, N., \& Van Praag, C. M. (2002). Low risk aversion encourages the choice for entrepreneurship: an empirical test of a truism. Journal of Economic Behavior \& Organization, 48, 29-36. http://dx.doi.org/10.1016/S0167-2681(01)00222-0

Cressy, R. (2000). Credit rationing or entrepreneurial risk aversion? An alternative explanation for the Evans and Jovanovic finding. Economics Letters, 66, 235-240. http://dx.doi.org/10.1016/S0165-1765(99)00216-5

Cupido, C. (2002). Barriers to Entrepreneurship in the Western Cape. Cape Town: Thesis submittod in fulfilment of the requirements for the Master Degree in the Faculty of Management at CAPE TECHNIKON.

De Soto, H. (1990). The Other Path. New York: Harper and Row.

Dickson, P., \& Giglierano, J. (1986). Missing the boat and sinking the boat: A conceptual model of entrepreneurial risk. Journal of Marketing, 50, 58-70. http://dx.doi.org/10.2307/1251585

Dutz, M. A., Ordover, J. A., \& Willig, R. D. (2000). Entrepreneurship, access policy and economic development: Lessons from industrial organization. European Economic Review, 44, 739-747. http://dx.doi.org/10.1016/S0014-2921(00)00030-1

Evans, D. (1989). Some Empirical Aspects of Entrepreneurship. American Economic Review, 79, 519-535.

Fairlie, R. W., Kapur, K., \& Gates, S. (2010). Is employer-based health insurance a barrier to entrepreneurship? Journal of Health Economics, 30, 146-162. http://dx.doi.org/10.1016/j.jhealeco.2010.09.003

Gable, M., Topol, M. T., Mathis, S., \& Fisher, M. F. (1995). Entry barriers in retailing. Journal of Retailing and Consumer Services, 2, 211-221. http://dx.doi.org/10.1016/0969-6989(95)00056-9

Gnyawali, D. R., \& Fogel, D. S. (1994). Environments for entrepreneurship development: key dimensions and research implications. Entrepreneurship Theory \& Practice, 18, 43-62.

Gorman, G., Hanlon, D., \& King, W. (1997). Some research perspectives on entrepreneurship education, enterprise education and education for small business management: a ten-year literature review. International Small Business Journal, 15, 56-77. http://dx.doi.org/10.1177/0266242697153004

Harada, N. (2003). Who succeeds as an entrepreneur? An analysis of the post-entry performance of new firms in Japan. Japan and the World Economy,15, 211-222. http://dx.doi.org/10.1016/S0922-1425(02)00002-6

Hirschman, A. (1958). The Strategy of Economic Development. New Haven: Yale University Press.

Humphrey, J. (2003). Opportunities for SMEs in developing countries to upgrade in a global economy. International Labour Organisation SEED working paper 43.

Hurst, E., \& Lusardi, A. (2004). Liquidity Constraints, Household Wealth and Entrepreneurship. Journal of Political Economy, 112, 319-347. http://dx.doi.org/10.1086/381478 
Ivy, R. (1997). Entrepreneurship strategies and problems in post-communist Europe: a survey of SMEs in Slovakia. Journal of Small Business Management, 35, 93-98.

Kanniainen, V., \& Poutvaara, P. (2007). Imperfect Transmission of Tacit Knowledge and Other Barriers to Entrepreneurship. International Conference on Entrepreneurship. Chicago.

Khayri, S., Yaghoubi, J., \& Yazdanpanah, M. (2011). Investigating barriers to enhance entrepreneurship in agricultural higher education from the perspective of graduate students. Procedia Social and Behavioral Sciences, 15, 2818-2822. http://dx.doi.org/10.1016/j.sbspro.2011.04.195

Kiggundu, M. (2002). Entrepreneurs and entrepreneurship in Africa: what is known and what needs to be done. Journal of Developmental Entrepreneurship, 7, 239-258.

Kihlstrom, R. E., \& Laffont, J. J. (1979). A general equilibrium theory of firm formation based on risk aversion. Journal of Political Economy, 87, 719-748. http://dx.doi.org/10.1086/260790

Klapper, L., Laeven, L., \& Rajan, R. (2004). Barriers to Entrepreneurship. Washington, DC.: The World Bank.

Klapper, L., Laeven, L., \& Rajan, R. (2006). Entry regulation as a barrier to entrepreneurship. Journal of Financial Economics, 82, 591-629. http://dx.doi.org/10.1016/j.jfineco.2005.09.006

Lazear, E. P. (2004). Balanced skills and entrepreneurship. The American Economic Review, 94, 208-211. http://dx.doi.org/10.1257/0002828041301425

Lopez, N. (1999). Barriers To Entrepreneurship: How Government Undermines Economic Opportunity. Lewisville: Institute for Policy Innovation.

Low, M. B., \& MacMillan, I. C. (1988). Entrepreneurship: Past Research and Future Challenges. Journal of Management, 14, 139-161. http://dx.doi.org/10.1177/014920638801400202

Lucas, R. J. (1978). On The Size Distribution of Business Firms. Bell Journal of Economics, 508-523. http://dx.doi.org/10.2307/3003596

Lundström, A., \& Stevenson, L. (2005). Entrepreneurship Policy: Theory and Practice. New York: Springer.

Mandal, A., \& Deshmukh, S. G. (1994). Vendor selection using interpretive structural management. International Journal of Operations \& Production Management, 14, 52-59. http://dx.doi.org/10.1108/01443579410062086

Martins, S. (2004). Barriers to entrepreneurship and business creation. Arouca, Portugal: European Entrepreneurship Cooperation.

McClelland, D. C. (1961). The Achieving Society. Princeton, NJ: Van Nostrand.

Newman, A. F. (2007). Risk-bearing and entrepreneurship. Journal of Economic Theory, 137, 11-26. http://dx.doi.org/10.1016/j.jet.2007.03.004

Niu, Y., Dong, L. C., \& Chen, R. (2011). Market entry barriers in China. Journal of Business Research.

Olson, M. (2000). Power and Prosperity: Outgrowing Communist and Capitalist Dictatorships. New York: Basic Books.

Onyebinama, U. A., \& Onyebinama, I. C. (2010). Extension education and entrepreneurship development in Nigerian agriculture. Agricultural Journal, 5, 63-69. http://dx.doi.org/10.3923/aj.2010.63.69

Qunlian, L. (2011). The major difficulties and countermeasures of current university graduates' entrepreneurship in China. Journal of Chinese Entrepreneurship, 3, 228-239. http://dx.doi.org/10.1108/17561391111167000

Rajaei, Y., Yaghoubi, J., \& Donyaei, H. (2011). Assessing effective factors in development of entrepreneurship in agricultural cooperatives of Zanjan province. Procedia Social and Behavioral Sciences, 15, 1521-1525. http://dx.doi.org/10.1016/j.sbspro.2011.03.323

Ramayah, T., \& Harun, Z. (2005). Entrepreneurial intention among the students of USM. International Journal of Management and Entrepreneurship, 1, 8-20.

Reynolds, P. D., Hay, M., \& Camp, S. M. (1999). The Global entrepreneurship monitor: 1999 executive report. Babson College: London Business School and the Kauffman Center for Entrepreneurial Leadership.

Sandhu, M. S., Sidique, S. F., \& Riaz, S. (2011). Entrepreneurship barriers and entrepreneurial inclination among Malaysian postgraduate students. International Journal of Entrepreneurial Behaviour \& Research, 17, 428-449. http://dx.doi.org/10.1108/13552551111139656 
Sarasvathy, S. (2004). The questions we ask and the questions we care about: reformulating some problems in entrepreneurship research. Journal of Business Venturing, 19, 707-717. http://dx.doi.org/10.1016/j.jbusvent.2003.09.006

Shapero, A. (1975). The displaced, uncomfortable entrepreneur. Psychology Today, 8, 83-88.

Singh, M. D., \& Kant, R. (2008). Knowledge management barriers: An interpretive structural modeling approach. International Journal of Management Science and Engineering Management, 3, 141-150.

Soysekerci, S., \& Erturgut, R. (2010). Improvement of non-governmental organization entrepreneurship in vocational schools: Turkey case. Procedia Social and Behavioral Sciences, 2, 1849-1854. http://dx.doi.org/10.1016/j.sbspro.2010.03.997

Talib, F., Rahman, Z., \& Qureshi, M. N. (2011). Analysis of interaction among the barriers to total quality management implementation using interpretive structural modeling approach. Benchmarking: An International Journal, 18, 563-587. http://dx.doi.org/10.1108/14635771111147641

Thakkar, J., Kanda, A., \& Deshmukh, S. G. (2008). Interpretive structural modeling (ISM) of IT-enablers for Indian manufacturing SMEs. Information Management \& Computer Security, 16, 113-136. http://dx.doi.org/10.1108/09685220810879609

Timmons, I. A. (1999). New venture creation: entrepreneurship for the 21th century. Singapore: McGraw-Hill.

Van de Ven, A., Hudson, R., \& Schroeder, D. (1984). Designing new business start-ups: Entrepreneurial, organizational, and ecological considerations. Journal of Management, 10, 87-107. http://dx.doi.org/10.1177/014920638401000108

Vesper, K. (1983). Entrepreneurship and national policy. Pittsburgh: Carnegie-Mellon University.

Wang, C. K., \& Wong, P. K. (2004). Entrepreneurial interest of university students in Singapore. Technovation, 24, 161-172. http://dx.doi.org/10.1016/S0166-4972(02)00016-0

Wang, G., Wang, Y., \& Zhao, T. (2008). Analysis of interactions among barriers to energy saving in China. Energy Policy, 36, 1879-1889. http://dx.doi.org/10.1016/j.enpol.2008.02.006

Warfield, J. W. (1974). Developing interconnected matrices in structural modeling. IEEE Transcript on Systems, Men and Cybernetics, 4, 51-81.

Yaghoubi, J. (2010). Study barriers to entrepreneurship promotion in agriculture higher education. Procedia Social and Behavioral Sciences, 2, 1901-1905. http://dx.doi.org/10.1016/j.sbspro.2010.03.1006

Yusuf, A. (1995). Critical success factors for small business: Perceptions of south pacific entrepreneurs. Journal of Small Business Management, 33, 68-73.

Zhang, Z., Zyphur, M. J., Narayanan, J., Arvey, R. D., Chaturvedi, S., Avolio, B. J., et al. (2009). The genetic basis of entrepreneurship: Effects of gender and personality. Organizational Behavior and Human Decision Processes, 110, 93-107. http://dx.doi.org/10.1016/j.obhdp.2009.07.002

\section{Copyrights}

Copyright for this article is retained by the author(s), with first publication rights granted to the journal.

This is an open-access article distributed under the terms and conditions of the Creative Commons Attribution license (http://creativecommons.org/licenses/by/3.0/). 